\title{
WEBINAR PENGGUNAAN MOODLE SEBAGAI MEDIA E-LEARNING UNTUK GURU-GURU DI JAWA BARAT
}

\author{
Tiawan, Afzeri Tamsir, Emmanuel Agung Nugroho, Deni Kurnia \\ Politeknik Enjinering Indorama \\ tiawan@pei.ac.id
}

\begin{abstract}
Learning systems using information technology is a necessity that must be done in this era, conventional learning systems by relying on face to face, the many administrations that must be prepared by teachers can hinder the acceleration of the transfer of knowledge from teachers to students. Amid the current global demands marked by the acceleration of the growth of information technology, the improvement of learning methods is also a demand that must be followed by teachers both at the secondary and elementary levels especially at the level of higher education, the current unfavorable situation with the corona virus outbreak is of concern nations including the Indonesian nation demand that teachers be more creative in delivering learning material by utilizing existing technological facilities. E-learning can be one of the breakthroughs to bridge the deadlock of direct communication between teachers and students and vice versa in teaching and learning activities. One of the tools that can be utilized in online learning models is Moodle. Moodle is one of the applications of the concepts and mechanisms of teaching and learning that utilize information technology, which is known as the concept of electronic learning or e-learning.
\end{abstract}

Keywords: e-learning; moodle; information technology.

\begin{abstract}
Abstrak
Sistem pembelajaran dengan memanfaatkan informasi teknologi merupakan suatu keniscayaan yang harus dilakukan pada era sekarang ini, sistem pembelajaran konvensional dengan mengandalkan tatap muka, banyaknya administrasi yang harus dipersiapkan oleh guru justru bias menghambat percepatan alih pengetahuan dari guru kepada para murid. Ditengah tuntutan global saat ini yang ditandai dengan percepatan pertumbuhan teknologi informasi maka peningkatan metode pembelajaran juga menjadi tuntutan yang harus diikuti oleh para guru baik pada tataran menengah dan dasar terlebih pada tataran pendidikan tinggi, situasi yang kurang baik sekarang dengan adanya wabah virus corona yang menjadi keprihatinan bangsa-bangsa termasuk bangsa Indonesia menuntut para guru untuk lebih kreatif menyampaikan materi pembelajaran dengan memanfaatkan fasilitas teknologi yang ada. E-learning bias menjadi salah satu terobosan untuk menjembatani buntunya komunikasi langsung antara guru kepada siswa dan sebaliknya dalam kegiatan belajar mengajar. Salah satu tools yang bias dimanfaatkan dalam model pembelajaran online adalah Moodle. Moodle merupakan salah satu aplikasi dari konsep dan mekanisme belajar mengajar yang memanfaatkan teknologi informasi, yang dikenal dengan konsep pembelajaran elektronik atau e-learning.
\end{abstract}

Kata Kunci: pembelajaran online; moodle; teknologi informasi.

Submitted: 2020-09-03 $\quad$ Revised: 2020-09-15 $\quad$ Accepted: 2020-09-21

\section{Pendahuluan}

E-learning bisa menjadi salah satu terobosan untuk menjembatani buntunya komunikasi langsung antara guru kepada siswa dan sebaliknya dalam kegiatan belajar mengajar, salah satu tools yang bisa dimanfaatkan dalam model pembelajaran online adalah moodle. Moodle adalah platform pembelajaran yang dirancang untuk memberi para pendidik, administrator, dan peserta didik satu sistem yang kuat, aman, dan 
terintegrasi untuk menciptakan lingkungan belajar yang dipersonalisasi. Secara umum dalam mempersiapkan sistem e-learning dalam suatu institusi pendidikan terdapat beberapa pilihan yang dapat diambil, salah satunya yaitu dengan menggunakan open source e-learning sistem. Saat ini telah terdapat beberapa sistem E-learning berbasis open source seperti Moodle, Dokeos, Sakai, Claroline dan lainnya. Pemanfaatan software open source ini tidak diperlukan biaya atau gratis. E-learning menawarkan kesempatan baru kepada pengajar dan pembelajar untuk memperkaya pengalaman belajar mengajar melalui lingkungan maya (virtual) yang mendukung bukan hanya penyampaian materi namun juga penggalian dan aplikasi dari informasi serta pemahaman terhadap pengetahuan baru. E-learning merupakan proses belajar secara efektif yang dihasilkan dengan cara menggabungkan penyampaian materi secara digital yang terdiri dari dukungan dan layanan belajar. Pengabdian ini bertujuan untuk mengedukasi guru-guru se-Jawa Barat menggunakan media pembelajaran moodle sebagai media pembelajaran daring. Dalam pengembangannya Moodle menggunakan empat konsep utama yaitu:

1. Paham konstruktif (Construcktivism)

2. Paham konstruksi (Constructionism)

3. Paham konstruktif sosial (Social Construcktivism)

4. Terkoneksi dan terpisah

\section{Metode}

Metode yang digunakan untuk mencapai tujuan dan target yang diharapkan adalah dengan Ceramah, Tanya Jawab dan Praktek. Materi yang diberikan yaitu Penggunaan LMS Moodle sebagai media online, setup materi pembelajaran, pembuatan tugas dan ujian, pengelolaan user. Tahapan pelaksanaan kegiatan ini dapat digambarkan dengan langkah-langkah sebagai berikut :

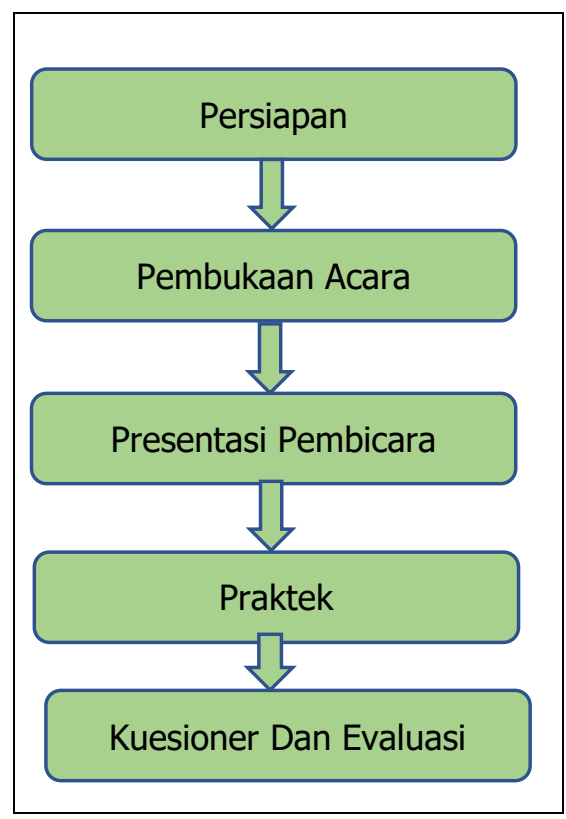

Gambar 1. Langkah Pelaksanaan Kegiatan 
Persiapan meliputi kegiatan mempersiapkan kebutuhan moodle Politeknik Enjinering Indorama terdiri dari persiapan materi. Pembukaan acara memperkenalkan Politeknik Enjinering Indorama kepada para Guru-Guru di Jawa Barat . Kegiatan inti adalah praktek yaitu pemateri menyampaikan materi dan para peserta mengikuti dengan mempraktekan materi yang diberikan. Kegiatan terakhir adalah pengisian kuesioner dan evaluasi. Adapun aspek penilaian kuesioner menggunakan skala likert 1-5 dapat dilihat pada tabel 1.

Tabel 1. Aspek Penilaian Kuesioner

\begin{tabular}{lll}
\hline No & Aspek Penilaian & Skor Nilai \\
\hline 1 & Kepuasan peserta mengikuti kegiatan PkM \\
2 & $\begin{array}{l}\text { Adanya perubahan sikap, pengetahuan dan keterampilan setelah } \\
\text { mengikuti kegiatan PkM }\end{array}$ \\
3 & $\begin{array}{l}\text { Adanya pemanfaatan ilmu pengetahuan dan teknologi yang telah } \\
\text { dibagikan secara berkelanjutan }\end{array}$ \\
4 & $\begin{array}{l}\text { Peserta kegiatan dapat mempraktekkan Ilmu pengetahuan dan } \\
\text { teknologi yang di dapat dari kegiatan PKM }\end{array}$ \\
5 & $\begin{array}{l}\text { Dapat membantu permasalahan yang dimiliki peserta seputar } \\
\text { materi yang diberikan lewat kegiatan PkM }\end{array}$ \\
\hline & Umpan Balik untuk mengadakan kegiatan PkM kembali \\
\hline
\end{tabular}

Interval penilaian kepuasan adalah sebagai berikut :

Indeks $80 \%-100 \% \quad$ : Sangat Puas / Sangat Setuju

Indeks $60 \%-79,99 \% \quad$ : Puas / Setuju

Indeks 40\% - 59,99\% : : Cukup Puas / Cukup Setuju

Indeks $20 \%-39,99 \% \quad$ : Kurang Puas / Kurang Setuju

Indeks $0 \% \quad-19,99 \% \quad$ : Tidak Puas / Tidak Setuju

\section{Hasil dan Pembahasan}

Pengabdian pada masyarakat diselenggarakan secara online melalui aplikasi zoom pada tanggal 9 Juli 2020, para peserta yang terdiri dari guru-guru yang ada di Jawa Barat sangat antusias dengan hadirnya acara tersebut. Hasil yang diperoleh dari pengabdian ini adalah sebagai berikut.

1. Peserta yang hadir pada acara pengabdian itu sejumlah 24 guru.

2. Materi yang diberikan pada pengabdian ini meliputi Penggunaan LMS dan Moodle sebagai media online, setup materi pembelajaran, Pembuatan Tugas dan Ujian, dan Pengelolaan User.

3. Para peserta yang mengikuti pelatihan merasa senang dan puas dengan kegiatan pengabdian ini, hal ini terlihat dari ungkapan kepuasan serta keantusiasan peserta mendengarkan dan bertanya berbagai hal tentang materi yang telah diberikan oleh para pengabdi dari dosen Politeknik Enjinering Indorama.

4. Kegiatan pengabdian ini dianggap oleh peserta sebagai sarana pengenalan dan pembelajaran mengenai aplikasi E-learning Moodle.

5. Pada acara penutupan, hampir seluruh para peserta mengharapkan agar program serupa diadakan kembali untuk lebih memahami mengenai aplikasi E-learning Moodle. 

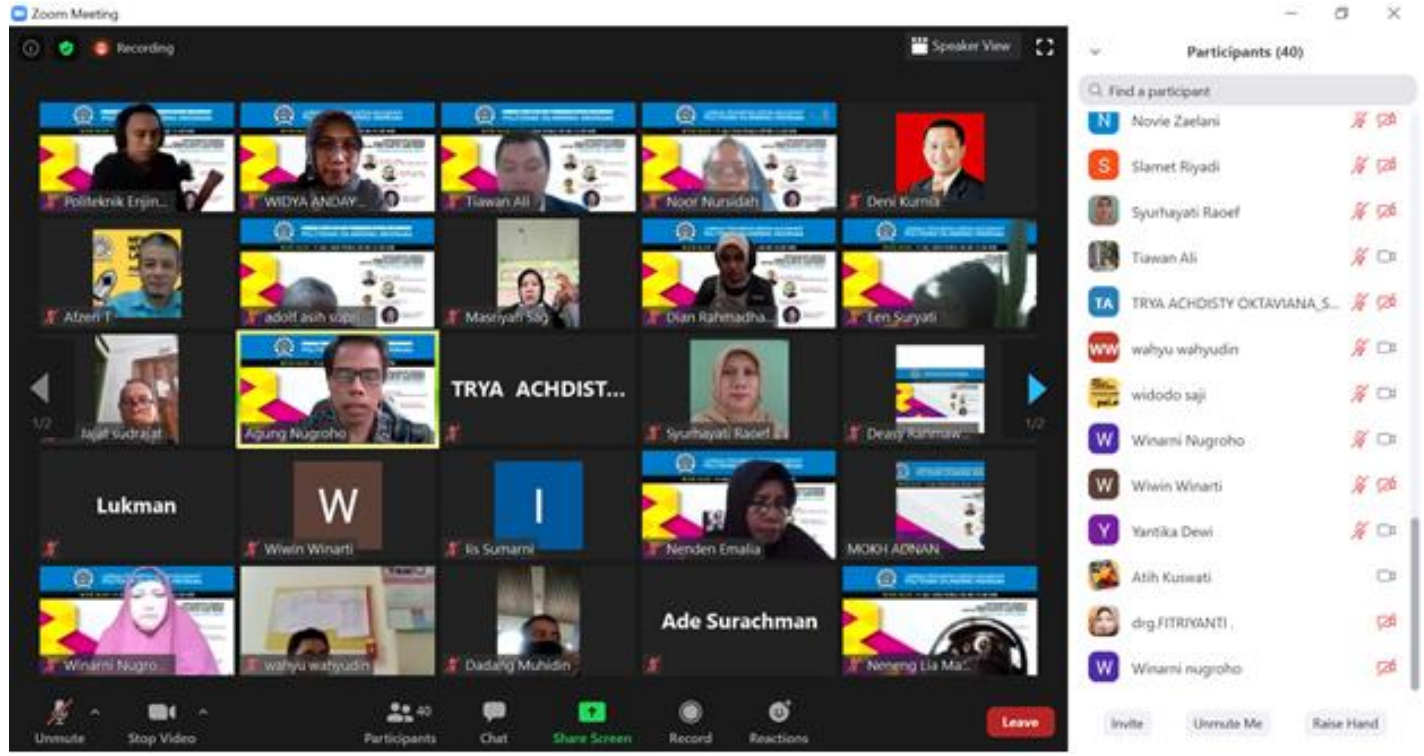

Gambar 2. Pemberian Materi E-Learning Moodle

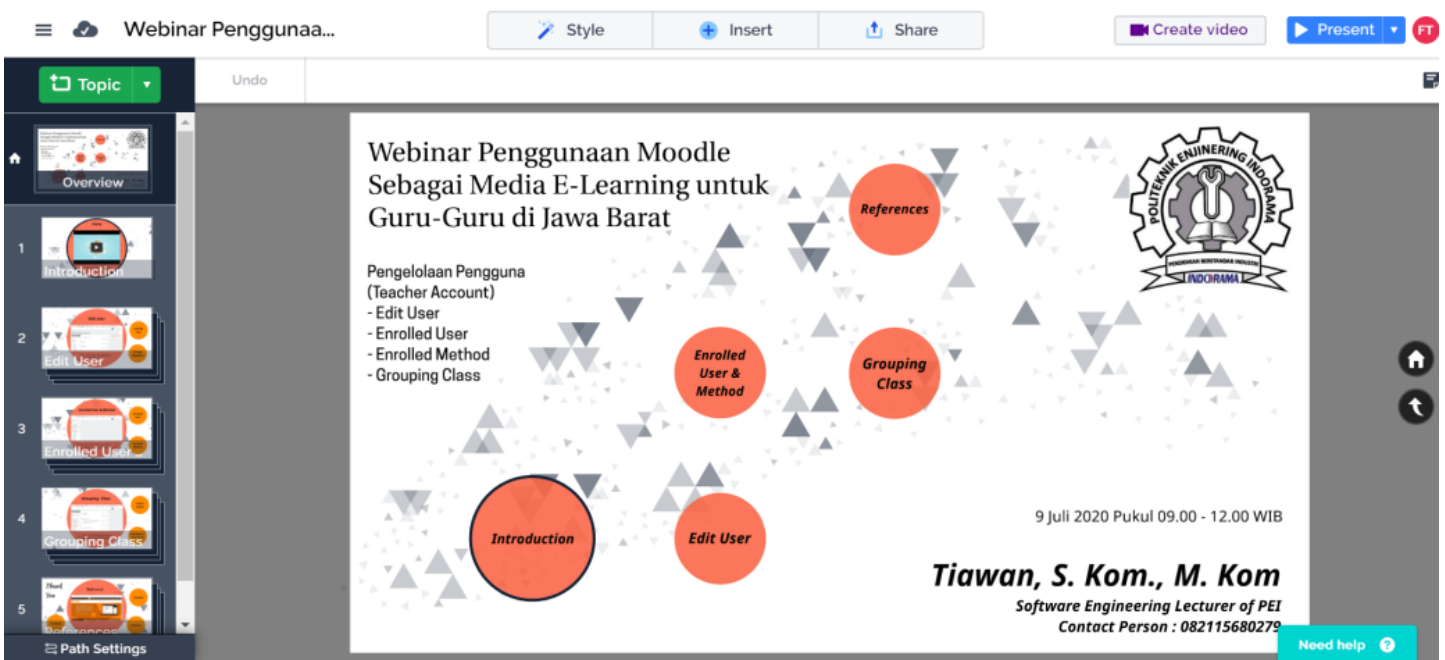

Gambar 3. Materi Online Moodle menggunakan Prezi

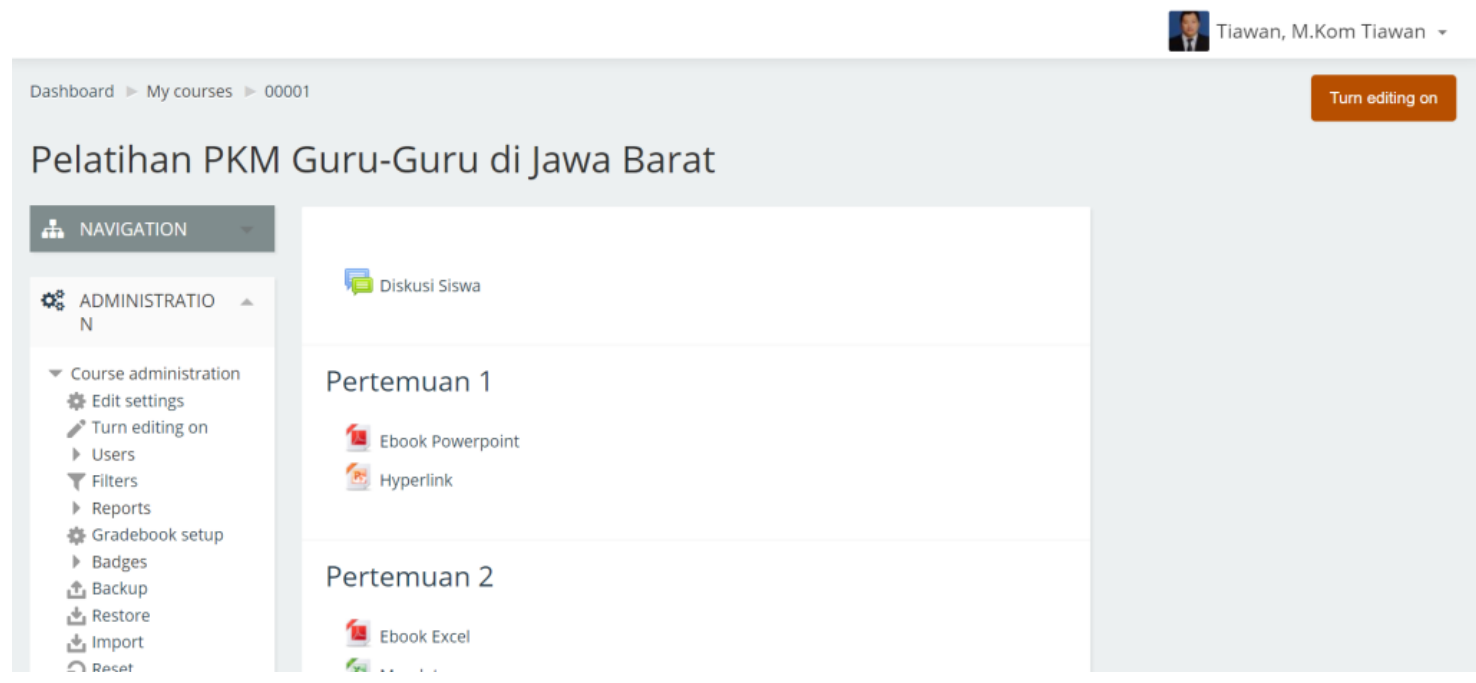

Gambar 4. Moodle PEI untuk PkM Guru-Guru 
Hasil pengisian Kuesioner kepuasan peserta dapat dilihat dari tabel 2

Tabel 2. Hasil kuesioner Kepuasan Peserta

\begin{tabular}{clc}
\hline No & \multicolumn{1}{c}{ Aspek Penilaian } & Skor Nilai \\
\hline 1 & Kepuasan peserta mengikuti kegiatan PkM & $83,3 \%$ \\
2 & $\begin{array}{l}\text { Adanya perubahan sikap, pengetahuan dan } \\
\text { keterampilan setelah mengikuti kegiatan PkM }\end{array}$ & $79,2 \%$ \\
3 & $\begin{array}{l}\text { Adanya pemanfaatan ilmu pengetahuan dan teknologi } \\
\text { yang telah dibagikan secara berkelanjutan }\end{array}$ & $75 \%$ \\
4 & $\begin{array}{l}\text { Peserta kegiatan dapat mempraktekkan Ilmu } \\
\text { pengetahuan dan teknologi yang di dapat dari } \\
\text { kegiatan PKM }\end{array}$ & $86,4 \%$ \\
5 & $\begin{array}{l}\text { Dapat membantu permasalahan yang dimiliki peserta } \\
\text { seputar materi yang diberikan lewat kegiatan PkM } \\
6\end{array}$ & $82,6 \%$ \\
& $\begin{array}{l}\text { Umpan Balik untuk mengadakan kegiatan PkM } \\
\text { kembali }\end{array}$ & $91,7 \%$ \\
\hline
\end{tabular}

Dari tabel 2 diperoleh nilai persentase rata-rata 83,03\% untuk PkM Moodle guru-guru di Jawa Barat, yang artinya peserta sangat setuju bahwa pelaksanaan PKM ini dapat membantu dalam meningkatkan ilmu pengetahuan dan teknologi.

\section{Kesimpulan}

Secara umum kegiatan pengabdian ini berjalan lancar, dimulai dari kegiatan mengundang para guru, persiapan, pembukaan acara, pelaksanaan kegiatan pegabdian, sampai kepada penyusunan laporan. Berdasarkan diskusi yang diselenggarakan oleh Politeknik Enjinering Indorama (PEI) diperoleh kesimpulan bahwa para peserta pengabdian tersebut merasa senang dan puas. Hal ini dibuktikan dengan adanya permintaan dari para guru sebagai peserta agar kegiatan pengabdian ini diadakan berkelanjutan. Kegiatan webinar ini dapat menjadi agenda kegiatan rutin PEI. Kegiatan ini akan dilaksanakan setiap tahun dan menghadirkan narasumber baik dari dalam negeri maupun luar negeri. kegiatan ini juga dapat menjadi salah satu kegiatan kolaborasi antara PEI dengan institusi lainnya. Faktor-faktor yang mendukung pelaksanaan pengabdian sehingga dapat terlaksana dengan lancar sebagai berikut:

1. Tingginya antusiasme peserta pengabdian yaitu guru-guru di Jawa Barat

2. Manfaat yang besar atas tema pengabdian mengenai penggunaan aplikasi Moodle

3. Fasilitas dan semangat tim pengabdi yang mendukung kelancaran pengabdian. Selain factor pendukung, ada pula faktor penghambat yang mengakibatkan kegiatan pengabdian ini tidak mampu mencapai tujuan secara maksimal, yaitu:

a) Waktu pengabdian hanya 4 jam yaitu jam 08.00 sampai dengan 12.00 WIB mengakibatkan peserta belum maksimal dalam menyerap materi.

b) Materi yang disampaikan belum termasuk materi tentang setup maupun installasi aplikasi moodle.

Berdasarkan uraian pelaksanaan kegiatan pengabdian ini, maka dapat ditarik kesimpulan sebagai berikut.

1. Peserta sangat setuju dengan kegiatan PkM Moodle yang dilakukan dengan persentase $83,03 \%$ 
2. Kegiatan pengabdian ini dapat dikategorikan berhasil dari segi partisipasi peserta mengingat dihadiri oleh 24 orang guru di Jawa Barat.

3. Peserta pengabdian sangat merasa senang dan puas dengan kegiatan pengabdian dan meminta agar pengabdian serupa dilaksanakan berkesinambungan mengingat pelatihan aplikasi Moodle ini sangat membantu guru-guru dalam pembelajaran daring.

4. dengan kegiatan pengabdian. Sikap itu ditunjukkan oleh permintaan agar pengabdian serupa dilaksanakan kembali dengan program pelatihan moodle lanjutan.

5. Para peserta merasa memperoleh wawasan baru tentang penggunaan aplikasi moodle.

\section{Daftar Pustaka}

Ali, Irsan Taufik, Analisis Hubungan Implementasi Multimedia pada Learning Management System terhadap Kemampuan Mahasiswa dalam Penguasaan Materi Pembelajaran. Jurnal Sains dan Teknologi, 2011, Vol. 10 No. 1, Hal. 3.

Ariyanti, F. E. 2013. Pengembangan Website Berbasis Moodle Melalui Blended Learning Untuk Mengefektifkan Ketrampilan Proses dan Hasil Belajar Kognitif Siswa Kelas X SMK Maospati. Jurnal Ilmiah Pendidikan, 1(1): 40-45

Komalasari, Kokom, Pembelajaran Kontekstual Konsep dan Aplikasi, Bandung: PT Refika Aditama, 2010.

Munir. 2012. Pembelajaran Jarak Jauh Berbasis Teknologi Informasi dan Komunikasi. Bandung: Alfabeta.

Graft, Sabine, Beate List, An Evaluation of Open Source E-Learning Platforms Stressing Adaptation Issues, Proceedings of the FifthIEEE International Conference onAdvance Learning Technologies (ICALT'05). 2005

Prakoso, K. 2005. Membangun E-learning dengan MOODLE. Yogyakarta: ANDI

Rusman dkk, Pembelajaran Berbasis Teknologi Informasi dan Komunikasi, 2011, Jakarta: PT. Raja Grafindo Persada. Hal. 245

Soekartawi, Bagaimana Peran, Prospek dan Masalah e-Learning dan ICT dalam Pendidikan Jarak Jauh di Indonesia. Seminar e-Learning dan Pembelajaran Terbuka/JarakJauh: Masalah dan Prospek, Lembaga Manajemen PPM, Jakarta, 20 April 2004.

Sriwardiningsih, E, Faktor-Faktor Yang Memengaruhi Perilaku Belajar Mahasiswa ELearning.Jurnal BINUS BUSINESS REVIEW, 2014, vol 5 no. 2, hal. 564-570

Surjono, H. D. 2013. Membangun E-learning dengan Moodle. Yogyakarta: PT. Andi https://docs.moodle.org/39/en/About Moodle [diakses 9 Juli 2020] 